самосвідомості, прагненню різноетнічних спільнот Західної України до національного самовираження. Національно-об'єднувальна функція музичних товариств найбільше виявилася у домінуванні хорового виконавства як найбільш демократичного виду музикування в регіональній культурній традиції. Активні міжнаціональні контакти у хоровій сфері зумовили динаміку активізації та професіоналізації музичного життя на теренах Західної України.

\title{
Література:
}

1. Мазепа Т. Соціокультурний феномен європейських музичних товариств XIX - початку XX століть на прикладі Галицького Музичного Товариства : монографія. Львів : Растр-7, 2017. 472 с.

2. Монолатій I. Особливості міжетнічних взаємин у західноукраїнському регіоні в Модерну добу : монографія. Івано-Франківськ : Лілея-НВ, 2007. 280 c.

3. Ханик Л. Р. Історія хорового товариства «Боян». Львів : Поліграфічний технікум УАД, 1999. 122 с.

DOI https://doi.org/10.30525/978-9934-26-004-9-16

\section{ДЖАЗ ТА УКРАЇНСЬКИЙ МЕЛОС В ІСТОРИЧНІЙ ДИНАМІЩ ЖАНРУ ОБРОБКИ НАРОДНОЇ ПІСНІ}

\author{
Соловйов А. М. \\ аспірант кафедри образотворчого мистецтва, \\ музикознавства та культурологіi \\ Науковий керівник: Зав'ялова О. К. \\ доктор мистецтвознавства, професор \\ Сумського державного педагогічного університету \\ імені А. С. Макаренка \\ м. Суми, Украӥна
}

Велика кількість джазменів різних напрямів сьогодні звертаються до народного українського мелосу та жанру його обробки. Відповідна концертна практика демонструє багату палітру індивідуальних композиційних прийомів оригінального прочитання народної пісні. Під «обробкою» ми розуміємо відтворення фольклорного першоджерела у новому культурному просторі: від едиційного (нотація зразків усної 
традиції), до творчо-мистецького. Під джазовою обробкою - відтворення народного мелосу у джазовій стилістиці.

Існує три типи обробки народної пісні, з яких у джазі реалізуються лише другій та третій типи. Перший тип - переважно фольклористичний, це нотно-текстова фіксація усної традиції, яка реалізує прагнення зберегти й відтворити фольклорне джерело. Другий mun, що підкорений ідеї популяризації народної пісні, представляє собою обробку по типу гармонізації або інструментального аранжування. Tретій тип відображає прагнення композитора-виконавця створити національний образ на основі фольклорного первню у власної концепції. Розглянемо вказані типи обробки в історичній динаміці розвитку жанру обробки у джазі в українській музичній культурі.

Етап 1960-х років видається важливим у становленні власне українського джазу, оскільки утворено Київській джаз-клуб, у якому розпочинається діяльність композитора, музикознавця Володимира Симоненка (1940-1998) - автора численних досліджень про джаз в Україні. Проведення перших фестивалів, починаючи від «Jam session» 1967 року сприяє стильовому урізноманітненню джазового напряму та переходу від біг-бендів до формату малих комбо. Саме у ці роки ансамбль Ігоря Хоми «Medicus» (колишня назва - «Ритм») був першим, хто спробував поєднати українську народну музику і джаз у обробці танцювальної весільної пісні «Гей, музики прошу, прошу», що презентовано ансамблем «Medicus». В композиції звучав інструментальний вступ у стилі бандурного награвання, а потім - ліричний вокал солістки у суто джазовому супроводі.

3 набуттям незалежності нашої держави в Україні активізується зацікавленість особливостями національної фольклорної культури. У творчості естрадно-джазових виконавців відбувається поєднання народного мелосу та елементів рок- та поп-музики, джазу, фанку й регі. Процес розквітає наприкінці $1980-x$ та у $1990-$-х роках у зв'язку 3 поширенням фестивального руху. Обробкам українських народних пісень цього етапу притаманна емоційна контрастність, різкувате звучання з виділеними мідними інструментами та ударними. Цікаво, що особливості народного метроритму 3 вільними побудовами, імпровізаційністю виконання, «білим звуком» народного вокалу гармоніюють з іманентними джазовими особливостями.

До напряму джазової обробки народної пісні у XXI столітті звертається багато видатних музикантів світу, а українські митці зараз створюють оригінальну мистецьку традицію втілення національного мелосу в зазначеному жанрі. Широко відомі авторські обробки пісень, 
виконані такими інструменталістами, як Олександр Саратський, Ігор Закус, Роман Гриньків, Вероніка Тормахова, також - сольними вокалістами та мішаними бендами. Їх твори звучать 3 концертної естради авторитетних академічних установ, наприклад, Національної філармонії України, Великого залу Національної музичної академії України ім. П. І. Чайковського та привертають увагу слухачів та дослідників. Цікавою особливістю $є$ той факт, що джазові обробки українських пісень (імпровізаційні за сутністю) фіксуються нотами, видаються відповідні партитури (Саратський, 1917 [1]; Хрестоматія, 2020 [2]). Тобто, усна за творчою сутністю традиція джазового імпровізування фіксується у нотному запису і набуває нових якостей. Наприклад, виникають циклічні композиції, стверджується модель джазової сюїти нового типу 3 українським мелосом.

Джазовий цикл «Лемківська сюїта» саксофоніста Антона Пивоварова - одинадцятичастинна сюїта, що створена А. Пивоваровим для джазового квінтету (саксофон, клавішні, ударні, бас-гітара та вокал). Вона включає обробки лемківських пісень та джазові інструментальні інтерлюдії: Berdo, Berdovychko, Interlude I, Ne Liy Doidzhyk, Gorila Lypka, Do Lvova Dorozhechka, Mam Ya Kosu, Kosichku, Svit Misyachku, Hodyt Divcha Po Sadochku, Interlude II, Chiya Zh To Rolychka, Epilogue. Уci частини сюїти мають аналогічну структуру: початок кожної частини являє собою експозицію народної пісні, тобто вокальну цитату в джазовому аранжуванні, причому неквадратність метроритму та тактової структури народного джерела залишається незмінною, пізнаванною слухачем і своєрідною. Розробковий розділ кожної частини - це джазове імпровізування за всіма правилами його побудови. Вражає органіка «стомп-патернів», поліритміка непарних фраз, які накладаються на парний грув. Крім того, безтекстові імпровізації вокалістки, зливаються тембрально $з$ соло сопранового саксофона, за рахунок чого утворюється двоголосся. Репризний розділ повертає тематичний матеріал та поетичний текст народної пісні, причому всі поліакцентні метроритмічні фігури викладені тут у суто джазовому дусі. На рівні слухацького сприйняття процес чергування фолку (в експозиційному викладі) та джазової імпровізації (у розробковому епізоді) синтезується в єдине ціле саме в репризному розділі кожної композиції. Ця музика тримає паритетний баланс між фольклорним інтонуванням та ідіомами джазу, вона по-європейському вишукана і має неповторну власну мову.

Значним здобутком українського етноджазу $є$ альбом «Коломийки Live» (2007) відомого бас-гітариста, співзасновника проєкту «Jazz-Коло» Ігоря Закуса та Z-Band. Західноукраїнській жанр коломийки (композиція 
«Співаночки») стає надбудовою всіх частин композиції джаз-концерту. Вступним розділом концерту, закличною інтрадою, є інструментальний наїграш, де справжня трембіта $з$ iї глісандованим інтонуванням панує, а потім передає естафету флюгельгорну та трубі, потім - бас-гітарі. Народні теми в експозиції викладено вокально, досить близько до оригіналу. Примхливі ритмоформули, що рівномірно чергуються у восьмискладовій темі, цезури-паузи та семискладовий мотив-відповідь задають тематичне зерно для імпровізації інструменталістів, у пасажах яких витримується особливий лад коломийки. У розвиваючих розділах відбувається зближення типів інструментального та вокального інтонування: спільними є глісандо, вібрато довгого звука, численні форшлаги. Характерною $є$ поліметрія та політональність різних шарів фактури. Усі елементи обробки органічно поєднані.

Олександр Саратський - також $є$ автором численних обробок українських народних пісень у джазовому стилі. Ці обробки існують у вигляді партитур для біг-бенду, або спрямовані для віртуозного фортепіанного (сольного) виконавства. Майбутнього композитора навчали видатні вчителі-академісти: в Київському музичному училищі Л. С. Хейфець-Поляковський, блискучий учень Л. Ревуцького та Б. Лятошинського; у Ленінградській консерваторії ім. М. А. РимськогоКорсакова - Л. Г. Ковнацька, видатна науковиця, спеціаліст по музиці XX століття, зокрема, по історії англійської музики. О. Саратський закінчив консерваторію як теоретик у 1988, блискуче захистив диплом на досить інноваційну для тих часів тему про стиль фьюжн як явище сучасної музики. Український фольклор, втілений у джазовому стилі фортепіанної музики О. Саратського, демонструє органічний синтез українського мелосу й сучасної джазової імпровізації. Ним створені оригінальні джазові композиції на основі коломийок, колискових, весільних «плачок», різдвяних пісень і колядок. Відмітимо, що народнопісенні прототипи розгортаються у просторі джазових обробок композитора 3 неймовірною майстерністю. О. Саратський глибоко відчуває та аналізує жанровий канон фольклорної пісні (ладо-звукорядні особливості, метроритмічні та формотворчі тощо). Маестро також дотримується стильових канонів джазу та творчо втілює їх в особливих прийомах імпровізації на тему української народної пісні.

Інша композиторка наймолодшої генерації - Вероніка Тормахова $\epsilon$ універсально обдарованою творчою особистістю, що поєднує професії музикознавиці та композиторки. В. Тормахова - відома аранжувальниця, членкиня Спілки композиторів України та асоціації ASCAP (Американське об'єднання композиторів, аранжувальників та видавців). 
Так, навчання композиції в іiі творчому житті завжди поєднувалося із музично-теоретичною освітою. Як композиторка вона навчалася у класі професора Київської консерваторії Генадія Ляшенка, як науковиця - у класі українського теоретика Дмитра Терентьєва, під керівництвом якого В. Тормахова захистила дисертацію у 2007 році.

Обробки В. Тормахової майстерно демонструють безліч варіантів поєднання скарбів національної музики 3 елементами джазової стилістики. Такий симбіоз не $\epsilon$ простим механічним доданком ознак класичного джазу з відомими народними мелодіями, це, скоріше, вияв джазового мислення в органічному контексті фольклорного мелосу. Джазова стилістика вдало розкриває різні акценти сюжетних ліній народного тексту і за рахунок яскравої альтерованої акордики, бітбоксу, імпровізацій, свінгування, динамізує їх плинну статику, закладену каноном повторності у традицію народного співу.

\title{
Література:
}

1. Саратський О. Цвіте терен [Ноти]: джазові обробки українських народних пісень для фортепіано. Частини I та II. Київ : Муз. Україна, $2017.60 \mathrm{c}$.

2. Хрестоматія для чоловічого вокального ансамблю а капела: нотна збірка [упоряд. та заг. ред. В. М. Тормахова]. Київ : Видавництво Ліра-К, 2020. $180 \mathrm{c}$.

DOI https://doi.org/10.30525/978-9934-26-004-9-17

\section{КЛАВІРНІ КОНЦЕРТИ Й. ГАЙДНА: АВТОРСТВО ТА ВИКОНАВСЬКА ВАРІАНТНІСТЬ}

\author{
Соловйова О. А. \\ аспірант кафедри образотворчого мистецттва, \\ музикознавства та культурологіі \\ Сумського державного педагогічного університету \\ імені А. С. Макаренка \\ м. Суми, Україна
}

Пріоритетні жанри віденського класицизму - симфонія, концерт, соната стали провідними в творчості його засновника Йозефа Гайдна. Майже тридцять років його життя було пов'язано зі службою в відомій 